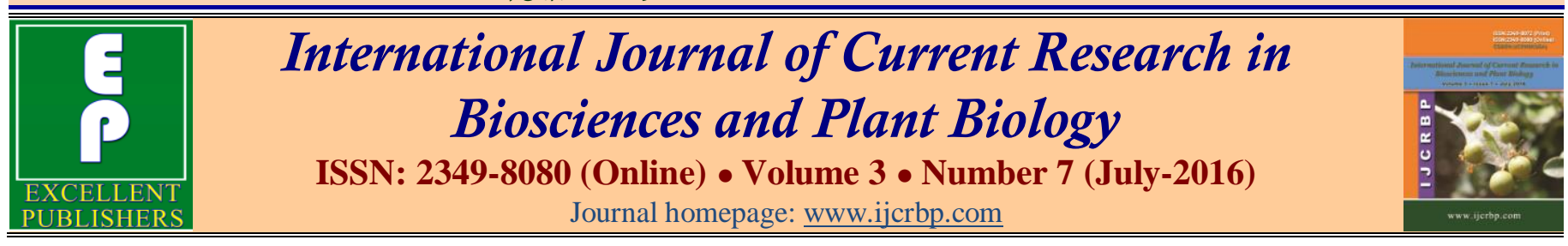

\title{
Phytochemical Screening of the Fruit of Garcinia cochinchinensis Choisy
}

\author{
Flavia Maria Vasques Farinazzi-Machado ${ }^{1 *}$, Sandra Maria Barbalho, ${ }^{1,2}$, Elen Landgraf

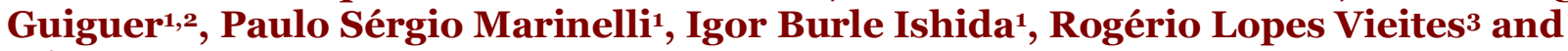 \\ Milton Groppo 4
}

${ }^{1}$ Department of Biochemistry and Nutrition, Faculty of Food Technology of Marilia (FATEC), Av. Castro Alves, 62, Marilia 17506-ooo, SP, Brazil

${ }^{2}$ Department of Biochemistry and Pharmacology, School of Medicine, University of Marilia, Av. Higino Muzzi Filho 1001, Marilia 15525-902, SP, Brazil

3 Faculty of Agronomic Sciences, University Estadual Paulista - UNESP - Botucatu, SP 18618970 Brazil

4Ribeirão Preto School of Philosophy, Sciences and Literature, University of São Paulo, Ribeirão Preto, Brazil

*Corresponding author.

\begin{abstract}
Among the native fruits, Garcinia genus is composed of many fruit species used by traditional medicine. Since there are no reports in the literature about the chemical composition of the false mangosteen (Garcinia cochinchinensis), the present study was aimed to perform the physicochemical screening and analysis of the presence of phytochemicals in the fruit pulp of this plant. Analysis of titratable acidity, soluble solids and $\mathrm{pH}$ were performed in the fresh fruit and vitamin $\mathrm{C}$, anthocyanins and carotenoids in fresh, dehydrated and frozen fruit after 30,60 and 90 days. Moreover, qualitative tests to check the presence of phytochemical compounds were also performed. Fresh fruit showed average values of $4.88 \pm 0.061$ for titratable acidity (g/100g of citric acid), $12.3 \pm 0.265$ for soluble solids ( ${ }^{\circ}$ Brix) and $\mathrm{pH} 2.52 \pm 0.067$. The average values for Anthocyanins and total carotenoids did not differ among fresh and frozen samples, but there was significant reduction in the levels of Vitamin C. Dehydrated fruit exhibited significantly higher levels of Carotenoids and Vitamin C compared to the fresh fruit, but lower values of Anthocyanins. Colorimetric analysis revealed the presence of phenols, flavonols, flavanones, flavanonols, xanthones and alkaloids in dehydrated G. cochinchinensis fruit.
\end{abstract}

\section{Introduction}

The daily consumption of fruits and vegetables has been epidemiologically associated with a lower incidence of morbidity and mortality by so-called chronic degenerative diseases, which include cancer, type 2 diabetes mellitus, hypertension, dyslipidemia, cardiovascular and cerebrovascular diseases. This association is strongly evidenced by the high content of phytochemical compounds with antioxidant and antiinflammatory properties as carotenoids, vitamins, and fibers in these foods (Gregoris et al., 2013; Pem and Jeewon, 2015; Oszmiański, et al., 2015; Cavallo et al., 2016).

Brazil is among the three largest producers of fruits, second only to China and India. In 2010 the country exported about 800 thousand tons (IBRAF, 2011). This high production of different varieties of native or adapted fruit is due to the extent of the territory and its different climates (Rocha et al., 2013; Virgolin, 2015). According to Lopes et al. (2012) and Sucupira et al. (2012) the 
native fruits are very rich both in nutritional and functional properties. Besides they present sensory characteristics such as color, distinct and pleasant aroma and flavor, and how they are adapted to local soils, practically do not require chemical inputs, and require low cost of implementation and maintenance of the orchard.

Garcinia genus (Clusiaceae) is composed of about 550 species, mostly trees, distributed mainly in tropical areas of Africa, America, Polynesia and Asia. Some species are extensively used by traditional medicine in various parts of the world, and some are fruit species such as Garcinia mangostana, G. buchananii, G. atroviridis, G. dulcis, $G$. xanthochymus and $G$. cochinchinensis. Phytochemical studies have revealed that species of Garcinia are rich sources of secondary metabolites, including flavonoids, biflavonoids, triterpenes and xanthones. Some of these compounds exhibit numerous biological activities, as anti-microbial, anti-cancer, antioxidant, anti-hyperlipidemic, and anti-inflammatory properties (Chen et al., 2010; Chang and Yang, 2012; Sukatta et al., 2013; Suttirak and Manurakchinakorn, 2014; Sharma et al., 2015; Stark et al., 2015; Kritsanawong et al., 2016).

Among the fruit species, the best known is the mangosteen (G. mangostana), considered an exotic and appreciable taste fruit originated from an Asia specie, that is used as fresh fruit, and is a considerable source of antioxidants, such as beta-carotene in the pulp and xanthones in the peel (Braga et al., 2012; Carvalho et al., 2014).

G. cochinchinensis is known as yellow mangosteen, Garcinia or false mangosteen, and is commonly confused with $G$. mangostana, especially in the young fruit stage. Once there are no reports in the literature about the chemical composition of $G$. cochinchinensis, the aim of this study was to perform the physicochemical screening and analysis of the presence of phytochemicals in the fruit pulp of this plant.

\section{Materials and methods}

\section{Raw material}

The false mangosteen fruit used in this study was obtained directly from the orchard in School of Food Technology (FATEC- Pompeia / São Paulo) in November 2015. The plant was identified and deposited in the Herbarium of the Department of Biology of FFCLRP-USP (Faculty of Philosophy, Sciences and
Languages of Ribeirão Preto - USP). Collector and number: M. Groppo 2307, registered at the herbarium under no. SPFR 16037.

In the Food Processing Laboratory of Fatec Marilia / São Paulo, the fruit was selected according to the healthy and they sanitized with sodium hypochlorite $(\mathrm{NaOCl}) 0.2 \mathrm{gL}^{-}$ ${ }^{1}$, followed by rinsing. The seeds were removed and the fruit pulp and peel were submitted to analysis in the fresh form. The fruit pulp was also stored in plastic bags and frozen (ultra-rapid freezing in $-80^{\circ} \mathrm{C}$ ).

\section{Phytochemical analysis of the fresh fruit}

The fresh fruit was macerated with the aid of a mixer, and underwent the analysis of titratable acidity $(\%(\mathrm{v} / \mathrm{v})$ of citric acid), soluble solids ( $\left.{ }^{\circ} \mathrm{Brix}\right)$ and $\mathrm{pH}$, according to the methodology of the Adolfo Lutz Institute (2008). After chemical analyzes the relation between soluble solids and titratable acidity was calculated (Ratio). Vitamin C content was expressed as $\mathrm{mg} / 100 \mathrm{~g}$ of the sample, and determined according to the reduction of 2,6-dichlorophenolindophenol indicator by ascorbic acid. Total carotenoids and anthocyanins were expressed as $\mathrm{mg} / 100 \mathrm{~g}$ and were analyzed by spectrophotometric method at wavelength of $450 \mathrm{~nm}$ and $535 \mathrm{~mm}$, respectively.

Further analyses were conducted after 30, 60 and 90 days after freezing for determination of carotenoids, vitamin C and anthocyanins. For the tests, the fruits were removed from the freezer and allowed to thaw at room temperature. All the parameters studied were performed in triplicate.

\section{Phytochemical analysis of the dehydrated fruit}

The fruit (without the seeds) was dehydrated in air circulating oven at $40^{\circ} \mathrm{C}$ for $96 \mathrm{hrs}$. Quantitative analyzes were carried out for vitamin C, carotenoids and anthocyanins (IAL, 2008). For the evaluation of the presence of phytochemicals, the dehydrated fruit was prepared according to the methodology described by Matos (1997), using ethanol 30\% as solvent. Tests for of phenols, tannins, flavones, flavonoids, xanthones, chalcones, flavononols, flavanones, catechins and alkaloids were performed.

\section{Statistical analysis}

Data were presented as median and standard deviations. Data analysis was performed by analysis of variance 
(ANOVA) and Tukey test using the Prism 6.0 software (GraphPad Software USA) with significance level of 5\% $(p<0.05)$.

\section{Results and discussion}

\section{Phytochemical analysis of the fresh fruit $(G$. cochinchinensis)}

An average of $4.88 \%$ of titratable acidity levels were found in the fresh pulp of the false mangosteen (Table 1).
Values between $3.85-4.42 \%$ were identified in fresh pulp of G. xanthochymus Hook (Cavalcante et al., 2006). Rufino (2008) in his study cites that bacuri also belonging to the Clusiaceae family, showed average values of $1.63 \%$ of Acidity titratable. The values for this parameter may be vary according to different kinds of processing methods, sensory and functional characteristics of certain kinds of fruit, which may be different due to genetic factors, place of production, harvest time, and the maturation stage (Batista et al., 2014).

Table 1. Acidity, soluble solids and $\mathrm{pH}$ in the fresh fruits of G. cochinchinensis.

\begin{tabular}{lllll}
\hline & Acidity [\% (v/v) of citric acid] & Soluble solids $\left({ }^{\circ} \mathbf{B}\right.$ rix $)$ & pH & Ratio \\
\cline { 2 - 5 } Fresh pulp & $4.887 \pm 0.061$ & $12.3 \pm 0.265$ & $2.52 \pm 0.067$ & $2.59 \pm 0.121$ \\
\hline
\end{tabular}

Mean \pm standard deviation

The fresh fruit showed mean values for $\mathrm{pH}$ and soluble solids of 2.52 and $12.3 \%$, respectively. Chavez-Cury et al. (2012) found values of $\mathrm{pH} 2.94$ for the variety $G$. madruno and in the pulp of the mangosteen ( $G$. mangostana). Roque et al. (2011) and Braga et al. (2012) showed mean values for $\mathrm{pH}$ of 2.9 and 3.25 , respectively. When comparing to the more acidic fruits, such as the different lemon cultivars - Galician (1.94), Tahiti (2.23) and Rangpur (2.35), and umbu-caja fruit (2.40), the mean values of $\mathrm{pH}$ of the false mangosteen pulp were higher, and showed also similar to fruits like passion fruit (2.51 to 2.63) (Brighenti et al., 2011; Santos et al., 2011; Canuto et al., 2010).

The levels of soluble solids of the fresh fruit were similar to those observed in pulp G. xanthochymus Hook (10.8 and $12.6^{\circ}$ Brix) (Cavalcante et al., 2006). Braga et al. (2012) showed lower values in G. mangostana (15.87\%). When comparing to citrus fruits, according to the study Couto and Canniatti-Brazaca (2010), the tangerine Ponkan possess values of soluble solids near to the false mangosteen this study. Murcott mandarin possess higher values $(14.33 \%)$, however, different varieties of oranges may exhibit levels ranging from $9.11 \%$ to $10.89 \%$.

Our results for the Ratio (SS / TA) were similar to those observed in the fresh pulp of the G. xanthochymus Hook (2.60 and 3.06) (Cavalcante et al., 2006). According to Chitarra and Chitarra (2005) the Ratio provides an indication of the flavor of the fruit, because it relates the content of sugars and acids, and tends to increase during ripening possibly because of the increase in the sugar and reduction in the acid content. It is also influenced by environmental or physiological factors, which directly interfere with the flavor of the fruit.

\section{Carotenoids, anthocyanins and vitamin $\mathrm{C}$ during the storage of the fruit}

In Table 2 we observe the results for carotenoids, anthocyanins and vitamin $\mathrm{C}$ found in the fresh fruit, and in the frozen samples.

Table 2. Levels of carotenoids, anthocyanins and vitamin $\mathrm{C}$ in the $G$. cochinchinensis, during the storage at $-80^{\circ} \mathrm{C}$.

\begin{tabular}{llllll}
\hline & Fresh fruit & 30 days & 60 days & 90 days & $p$-value* \\
\hline Carotenoids $(\mu \mathrm{g} / \mathrm{g})$ & $0.333 \pm 0.022$ & $0.395 \pm 0.141$ & $0.390 \pm 0.017$ & $0.383 \pm 0.187$ \\
Anthocyanins $(\mathrm{mg} / 100 \mathrm{~g})$ & $1.710 \pm 0.460$ & $1.113 \pm 0.196$ & $1.423 \pm 1.260$ & $1.503 \pm 0.206$ \\
Vitamin C $(\mathrm{mg} / 100 \mathrm{~g})$ & $11.62 \pm 0.0$ & $8.840 \pm 0.03$ & $8.060 \pm 0.11$ & $7.800 \pm 0.33$ & 0.5515 \\
\hline
\end{tabular}

Mean \pm standard deviation $/ * p$-value $<0.05$.

Fresh fruit presented average values of $0.33 \mathrm{mg} / \mathrm{g}$ to carotenoids, and during the storage period, significant losses were not observed in frozen samples. The values were lower when compared to other fruit as different mango cultivars that have, according to Silveira et al. (2009) values ranging from 11.0 to $28.2 \mathrm{~g} / \mathrm{g}$ in the carotenoids content. In papayas, fruit with significant concentrations of carotenoids, Reis et al. (2015) found values between 41.11 and $42.84 \mathrm{mg} / \mathrm{g}$. Sena et al. (2014) found values of $4.2 \mathrm{ug}, 4.3 \mathrm{ug}$ and $3.0 \mathrm{ug} / \mathrm{g}$ of acerola, soursop and tangerine samples, respectively. Matias et al. (2014) found values of 3.3 and $14.0 \mathrm{~g} / \mathrm{g}$ in yellow peach 
pulp. Lopes et al. (2005) observed a significant decrease in the total Carotenoids content in the first 30 days of storage in cherry pulps frozen at $-18^{\circ} \mathrm{C}$, however, in 45 , 60 and 90 days a significant reduction was not verified. Carotenoid levels may suffer significant losses in fruit and vegetables when they are cut or disintegrated due to exposure to oxygen and light, and contact with catalytic enzymes of the oxidation process (Rodriguez-Amaya, 1997; Niizu and Rodriguez-Amaya, 2005).

Vitamin C levels were lower than those observed in $G$. indica pulp indicates $(60 \mathrm{mg} / 100 \mathrm{~g})$ in a study of Krishnamurthy et al. (1982) and in the pulp of $G$. madruno $(24.74 \mathrm{mg} / 100 \mathrm{~g}$ ) as showed by Chavez-Cury et al. (2012). However, the values found in this work is higher when compared to other fruit as red plum (6.8 $\mathrm{mg} / 100 \mathrm{~g})$, apple $(8.0 \mathrm{mg} / 100 \mathrm{~g})$, white grape (4.6 $\mathrm{mg} / 100 \mathrm{~g}$ ) and watermelon $(9.0 \mathrm{mg} / 100 \mathrm{~g}$ ) (Zeraik et al., 2010; Chitarra and Chitarra, 2005; Harain et al., 2004).

The levels of Vitamin $\mathrm{C}$ decreased significantly during the storage period (p-value 0.0014). Reduction of $32.87 \%$ in the content of vitamin $\mathrm{C}$ was demonstrated after 90 days under freezing conditions. According to Silva et al. (2008), vitamin C is vulnerable to processing conditions and its degradation is directly related to many factors such as temperature, humidity, $\mathrm{pH}$, presence of antioxidants, oxygen and others. In a study by Silva et al. (2008) the concentration of vitamin C in frozen pulps of the fruit Cagaita reduced approximately $30 \%$ in the first month, and 50\% in the third month of storage. Brunini et al. (2002) found that the content of vitamin $C$ in mango frozen at $-18^{\circ} \mathrm{C}$, reduced from $56.11 \mathrm{mg} / 100 \mathrm{~g}$ to 23.85 $\mathrm{mg} / 100 \mathrm{~g}$ after 18 weeks.

In the fresh samples of $G$. cochinchinensis we found average values of $1.71 \mathrm{mg} / 100 \mathrm{~g}$ of anthocyanins, with concentrations did not vary significantly with the storage. These components are water-soluble pigments (tones from the red to blue color). However, its color is directly influenced by substitution of hydroxyl and methoxyl groups in the molecule, besides the existence of an intermolecular co-pigmentation with other compounds such as organic acids, flavonoids and alkaloids (Mazza and Brouillard, 1987; Lopes et al., 2007).

Some species of Garcinia with purple or red color possess higher contents of Anthocyanins when compared to yellow species such as $G$. indica Choisy and $G$. mangostana, whose concentration of Anthocyanins is very expressive in the bark of the fruit (Nayak et al.,
2010; Palapol et al., 2009). Kuskoski et al. (2006) did not identify the presence of these components in other yellow fruit as mango, pineapple and passion fruit but found values of 2.7 and $16 \mathrm{mg} / 100 \mathrm{~g}$ in guava and acerola pulp, respectively.

\section{Carotenoids, anthocyanins and vitamin $\mathrm{C}$ in the dehydrated fruit}

The dehydrated fruit presented $80.46 \mathrm{mg} / 100 \mathrm{~g}$ of vitamin C; $1.013 \mathrm{mg} / 100 \mathrm{~g}$ of Carotenoids and $1.71 \mathrm{mg} / 100 \mathrm{~g}$ of anthocyanins. In pulps of dehydrated apples were observed average values of $22.33 \mathrm{mg} / 100 \mathrm{~g}$ for vitamin C (Santos et al., 2013). In different types of dehydrated mango authors observed 76.57 and $36.22 \mathrm{mg} / 100 \mathrm{~g}$ of Vitamin C (Bezerra et al., 2011).

The dehydration process promotes the reduction of the free water under mild conditions with a reduction of the speed on the chemical, enzymatic and biochemical reactions that are responsible for the deterioration of the fruit. For this reason, this process can be a viable alternative to obtain products with high levels of nutrients and increased shelf life, besides preventing undesirable changes in color, aroma texture and flavor that occur during storage (Chong et al., 2013; Zhang et al., 2015).

Values for carotenoids were similar to those observed in atomized cashew pulp $(0.19 \mathrm{mg} / 100 \mathrm{~g})$ studied by Moraes (2014). The anthocyanins levels were lower than those described by Teixeira et al. (2011) in the evaluation of Caryocar brasiliense pulp dried in an oven (4.25 to $6.06 \mathrm{mg} / 100 \mathrm{~g}$ ). In a study by Silva et al. (2010) were observed levels of $51.57 \mathrm{mg} / 100 \mathrm{~g}$ and $52.90 \mathrm{mg} / 100 \mathrm{~g}$ of anthocyanins extracted from the bark of mangosteen $(G$. mangostana) at $40^{\circ} \mathrm{C}$ and $24^{\circ} \mathrm{C}$ respectively.

Comparatively, Carotenoids content and Vitamin C were significantly higher in samples of the dehydrated fruit. In contrast, Anthocyanins levels were lower in these samples (Table 3).

Table 3. Levels of carotenoids, anthocyanins and vitamin $\mathrm{C}$ in fresh and dehydrated fruit.

\begin{tabular}{llll}
\hline & $\begin{array}{l}\text { Carotenoids } \\
(\boldsymbol{\mu g} / \mathbf{g})\end{array}$ & $\begin{array}{l}\text { Anthocyanins } \\
(\mathbf{m g} / \mathbf{1 0 0 g})\end{array}$ & $\begin{array}{l}\text { Vitamin C } \\
(\mathbf{m g} / \mathbf{1 0 0 g})\end{array}$ \\
\hline $\begin{array}{l}\text { Fresh fruit } \\
\begin{array}{l}\text { Dehydratated } \\
\text { fruit }\end{array}\end{array}$ & $0.333 \pm 0.022$ & $1.711 \pm 0.102$ & $11.62 \pm 0.0$ \\
-value* $^{*}$ & $0.0074 \pm 0.118$ & $0.096 \pm 0.025$ & $80.45 \pm 0.010$ \\
\hline
\end{tabular}

Mean \pm standard deviation $/ * p$-value $<0.05$ 
Studies have shown that consumption of fruits such as natural juices or dehydrated fruits have contributed to maintaining the balance of the antioxidant system, the improvement in plasma levels of vitamins and other compounds of this nature (Samman et al., 2003; Tonin et al., 2015; Järvi et al., 2016).

The carotenoids have been related to beneficial effects on human health as enhancement of the immune response, reducing the risk of degenerative diseases such as cancer, cardiovascular disease, cataracts and macular degeneration associated with age (Kadian and Garg, 2012; Rodriguez-Bernaldo and Costa, 2006).

Ascorbic acid is an essential vitamin in humans and may exhibit antioxidant and anti-inflammatory activity protecting against the development of innumerous chronic diseases. It is associated with the production of collagen, noradrenalin and serotonin, and steroid hormones. It may act as a reducer component, preventing the oxidative and degenerative effects of the free radicals and may regenerate vitamin $\mathrm{E}$. It is also related to the modulation of the immunity system (Rutkowsku and Grzegorczyk, 2012; Miles et al., 2015; Li et al., 2015; Sato et al., 2015).

Anthocyanins also play relevant role as antioxidant. They consist in phenolic compounds with several important biological effects such as, anti-inflammatory and vasodilation. As they possess antioxidant and antiinflammatory properties, they are related to the prevention of inflammation process, diabetes, dyslipidemia, obesity, metabolic syndrome, cardiovascular diseases, and cancer. These pigments are very promising in the food technology due to the possibility to use them as functional foods components (Min et al., 2015; Skrovankoya et al., 2015).

\section{Evaluation of the presence of phytochemicals in the dehydrated fruit}

The colorimetric analysis revealed the presence of phenols, flavonols, flavanones, flavanonols, xanthones and alkaloids in the dehydrated Fruit of $G$. cochinchinensis (Table 4).

Colorimetric analyzes with $G$. mangostana revealed the presence of phenols, flavonoids and triterpenoids in extracts with hexane and chloroform in the fruit epicarp and endocarp (Sivakumari et al., 2016). Abdallah et al. (2016) identified bioactive components that may prevent the formation of advanced glucose end products that are responsible for the chronic complications of diabetes mellitus (D garcimangosone, aromadendrin-8-Cglucopyranoside, epicatechin and 2.3', 4.5', 6pentahydroxybenzophenone).

Table 4. Qualitative phytochemicals in the extract of G. cochinchinensis fruits.

\begin{tabular}{ll} 
Phytochemicals & $\begin{array}{l}\text { Extract of the dehydrated } \\
\text { fruit }\end{array}$ \\
\hline Phenols & + \\
Tannins & - \\
Flavones, flavonoids, & - \\
xanthones & - \\
Chalcones & + \\
Flavonoids & + \\
Flavanones & - \\
Catechins & + \\
Flavonols, flavanones, & \\
flavanonols, xanthone & + \\
Alkaloids & + \\
+ indicates presence of compounds / - indicates absence of \\
compounds.
\end{tabular}

Akao et al. (2008) found three types of xanthones $(\alpha, \beta$ and $\gamma$-mangostin) identified in the pericarp of $G$. mangostana that showed antioxidant and antiproliferative effects in cancer cells. Wihastuti et al (2014) observed reduction of mediators such as nuclear factor - kappa $\beta(\mathrm{NF}-\kappa \beta)$ and other reactive species involved in atherosclerosis when studying the effects of mangosteen in hypercholesterolemic Wistar rats.

Some studies have identified the presence of flavonoids (naringenin, binarigenin, morelloflavone and fukugiside) and other phenolic compounds (atroviridin, atrovirinone, atrovirisdone and atrovirisdone B, cambogin, garcinol, camboginal and isogarcinol) in mature fruit and leaves of G. atroviridis (MacKeen et al., 2002; Permana et al., 2005; Al-Mansoub et al., 2014).

Authors have found bioactive benzophenones compounds such as aristophenone A, alloathyriol, amentoflavone, guttiferone E, isoxanthochymol, gambogenone, and in $G$. xanthochymus fruit, demonstrating activity against colon cancer cells (Baggett et al., 2005).

Hassan et al. (2013) identified levels of phenolic compounds in the peel and pulp of G. parvifolia higher than those found in Fruit G. atroviridis and G. prainiana. These authors also showed the presence of high concentrations of total carotenoids, flavonoids and 
anthocyanins with significant antioxidant activity in pulp G. parvifolia.

Several studies have revealed extensive role of phenolic compounds in preventing disease and maintaining health of individuals. Once absorbed, they may modulate numerous pathophysiological processes such as inflammation, oxidative stress, high blood pressure, insulin resistance, mutagenic and microbiological processes by reducing the risk of development of many disorders (Rosa et al., 2016; Hügel et al., 2016; Ozkan et al., 2016). The intake of $G$. cochinchinensis may contribute with the consumption of these important components.

\section{Conclusion}

The results of the present study show that the consumption of $G$. cochinchinensis may be a good source of antioxidants such as vitamin $\mathrm{C}$, carotenoids, anthocyanins and other polyphenol compounds. The freezing of the fruit causes no interference with anthocyanin and carotenoid values and even reducing the levels of vitamin $\mathrm{C}$, we observe that after 90 days of freezing, almost $70 \%$ of this vitamin is still available. Moreover, even with the reduction of the vitamin $\mathrm{C}$ after freezing, the levels are still higher than other fruits such as apple, white grape, plum red and melon. These results show that the use of this fruit can extend to products with shelf life greater than the fresh fruit, preserving important nutrients.

\section{Conflict of interest statement}

Authors declare that they have no conflict of interest.

\section{References}

Abdallah, H. M., El-Bassossy, H., Mohamed, G., ElHalawany, A. M., Alshali, K. Z., Banjar, Z. M., 2016. Phenolics from Garcinia mangostana inhibit advanced glycation end products formation: Effect on Amadori products, cross-linked structures and protein thiols. Molecules. 22(1), 1-15.

Adolfo Lutz Institute. Normas Analíticas do Instituto Adolfo Lutz. 2008. Métodos químicos e físicos para análise de alimentos. 4. Edn. 1. Edn. digital. IMESP, 2008, São Paulo.

Akao, Y., Nakagawa, Y., Iinuma, M., Nozawa, Y., 2008. Anticancer effects of xanthones from pericarps of mangosteen. Int. J. Mol. Sci. 9(3), 355-370.

Al-Mansoub, M. A., Asmawi, M. Z.,, Murugaiyah, V., 2014. Antihyperlipidemic and antioxidant effects of Garcinia atroviridi. J. Sci. Food Agric. 94, 1552-1558.

Baggett, S., Protiva, P., Mazzola, E. P., Yang, H., Ressler, E. T, Basile, M. J., Weinstein, I. B., Kennelly, E. J., 2005. Bioactive benzophenones from Garcina xanthochymus fruits. J. Nat. Prod. 68(3), 354-360.

Batista, A. D., Fonseca, A. A. O., Costa, M. A. P. C., Bittencourt, N.S., 2014. Physical, physical-chemical and chemical characterization of fruit's surinam cherry originated on five municipalities of Bahia. Magis. 26(3), 397- 407.

Bezerra, T. S., Costa, J. M. C., Amorim, A. M. R., Arraes, M. G., Edmar, C., 2011. Avaliação físico-química e aplicação de modelos matemáticos na predição do comportamento de polpas de manga desidratadas em pó. Rev. Ceres. 58(3), 278-283.

Braga, A. C., Assis Neto, E. F., Vilhena, M. J. V., 2012. Elaboração e caracterização de iogurtes adicionados de polpa e de xarope de mangostão. Rev. Bras. Prod. Agr. 14(1), 77-84.

Brighenti, D. M., Carvalho, C. F., Brighenti, C. R. G., Carvalho, S. M., 2011. Inversão da sacarose utilizando ácido cítrico e suco de limão para preparo de dieta energética de Apis mellifera Linnaeus, 1758. Ciênc Agrotecnol. 35(2), 297-304.

Brunini, M. M., Durigan, J. F., Oliveira, A. L., 2002. Avaliação das alterações em polpa de manga 'tommyatkins' congeladas. Rev. Bras. Frutic. 24(3), 651-653.

Canuto, G. A. B., 2010. Caracterização físico-química de polpas de frutas da Amazônia e sua correlação com a atividade anti-radical livre. Rev. Bras. Frut. 32(4), 11961205.

Carvalho, J. E. U., 2014. Mangostanzeiro: botânica, propagação, cultivo e utilização. Rev Bras Frut. 36(1), 148-155.

Cavalcante, I. H. L., Jesus, N., Martins, A. B. G., 2006. Physical and chemical characterization of yellow mangosteen fruits. Rev. Bras. Frut. 28(2), 325-327.

Cavallo, D. N., Horino, M., McCarthy, W. J., 2016. Adult intake of minimally processed fruits and vegetables: Associations with cardiometabolic disease risk factors. J. Acad. Nutr. Diet. [Epub ahead of print].

Chang, H. F., Yang, L. L., 2012. Gamma-mangostin, a micronutrient of mangosteen fruit, induces apoptosis in human colon cancer cells. Molecules. 17(7), 8010-8021.

Chávez-Cury, G., Abela-Gisbert, M. C., Bravo-José, A., Peñarrieta, J. M., Rendón-Porcel, W. J., 2012. Estudio del fruto comestible de la especie vegetal Garcinia madruno. Rev. Bol. Quim. 29(1), 87-93.

Chen, Y., Fan, H., Yang, G.Z., Jiang, Y., Zhong, F. F., He, H. W., 2010. Prenylated xanthones from the bark of Garcinia xanthochymus and their 1,1-diphenyl-2-picrylhydrazyl (DPPH) radical scavenging activities. Molecules. 15(10), 7438-7449.

Chitarra, M. I. F., Chitarra, A. B., 2005. Pós-colheita de frutas e hortaliças: fisiologia e manuseio. 2nd Edn. Lavras: 
UFLA. $785 \mathrm{p}$.

Chong, C. H., Lawb, C. L, Figielc, A., Wojdyłod, A., Oziembłowskie, M., 2013. Colour, phenolic content and antioxidant capacity of some fruits dehydrated by a combination of different methods. Food Chem. 141(4), 3889-3896.

Couto, M. A. L., Canniatti-Brazaca, S. G., 2010. Quantificação de Vitamin $\mathrm{C}$ e capacidade antioxidante de variedades cítricas. Ciênc. Tecnol. Alim. 30(s1), 15-19.

Gregoris, E., Lima, P. P., Fabris, S., Bertelle, M., Sicari, M., Stevanato, R., 2013. Antioxidant properties of Brazilian tropical fruits by correlation between different assays. BioMed. Res. Inter. 2013, 132759.

Harain, N., Almeida, J. N., Galvão, M. S., Madruga, M. S., Brito, E. S. 2004. Compostos voláteis dos frutos do maracujá (Passiflora edulis forma Flavicarpa) e de cajá (Spondays mombin L.) obtidos pela técnica de headspace dinâmico. Cienc. Tecn. Alim. 24(2), 212-216.

Hassan, S. H.A., Fry, J. R., Bakar, M. F. A., 2013. Phytochemicals Content, Antioxidant Activity and Acetylcholinesterase Inhibition Properties of Indigenous G. parvifolia Fruit . BioMed Res. Int. 2013, 138950.

Hügel, H. M., Jackson, N., May, B., Zhang, A. L, Xue, C. C., 2016. Polyphenol protection and treatment of hypertension. Phytomedicine. 23(2), 220-231.

IBRAF-Instituto Brasileiro de Frutas, Estatísticas Frutas Frescas, 2011. Disponível em: (http://www.ibraf.org.br/estatisticas/Exporta\%C3\%A7\%C 3\%A3o/Comparativo_das_Exporta\%C3\%A7\%C3\%B5es_ Brasileiras_de_Frutas_frescas_2010-2009.pdf>. Acesso em: 16 mai. 2016.

Järvi, A., Karlström, B., Vessby, B., Becker, W., 2016. Increased intake of fruits and vegetables in overweight subjects: Effects on body weight, body composition, metabolic risk factors and dietary intake. Braz. J. Nutr. 115(10), 1760-1768.

Kadian, S. S., Garg, M., 2012. Pharmacological effects of carotenoids: A review. Int. J. Pharmac. Sci. Res. 3(1), 4244.

Krishnamurthy, N., Lewis, Y. S., Ravindranatha, B., 1982. Chemical constitution of Kokum fruit - rind. J. Food Sci. Technol. 19, 97-100.

Kritsanawong, S., Innajak, S., Imoto, M., Watanapokasin, R., 2016. Antiproliferative and apoptosis induction of $\alpha$ mangostin in T47D breast cancer cells. Int. J. Oncol. 48(5), 2155-2165.

Kuskoski, E. M., Asuero, A. G., Morales, M. T., Fett, R., 2006. Fruit tropicais silvestres e polpas de frutas congeladas: atividade antioxidante, polifenóis e Anthocyanins. Ciênc. Rural. 36(4), 1283-1287.

Li, K., Wang, J., Shi, M., Li, J., Yan, L., Zhang, H., Lu, C., 2015. Prescription consisting of Vitamin $\mathrm{C}$ and Baicalin inhibits tumor growth by enhancing the antioxidant capacity in vivo. J. Buon. 20(5), 1368-1372.

Lopes, A. S., Mattietto, R. A, Menezes, H. C., 2005.
Estabilidade da polpa de pitanga sob congelamento. Ciênc. Tecnol. Aliment. 25(3), 553-559.

Lopes, R. M., Silva, J. P., Vieira, R. F., Silva, D. B., 2012. Composição de ácidos graxos em polpa de frutas nativas do cerrado. Rev. Bras. Frutic. 34(2), 635-640.

Lopes, T. J., Xavier, M. F., Novy, M. G., Bastos, M., 2007. Anthocyanins: uma breve revisão das características estruturais e da estabilidade. Rev. Bras. Agrociênc. 13(3), 291-297.

Mackeen, M. M., Ali, A. M., Lajis, N. H., Kawazu, K., Kikuzaki, H., Nakatani, N., 2002. Antifungal Garcinia acid esters from the fruits of Garcinia atroviridis. Z. Naturforsch C. 57, 291-295.

Matias, R. G. P., da Silva, D. F. P., Ribeiro, M. R., 2014. Características de frutos de pessegueiros cultivados na Zona da Mata de Minas Gerais. Ciênc. Rural. 44(6), 971974.

Matos, F. J. A., 1997. Introdução a fitoquímica experimental. $2^{\mathrm{a}}$.ed. Fortaleza: UFC, 141p.

Mazza, G., Brouillard, R., 1987. Recent developments in the stabilization of anthocyanins in food products. Food Chem. 25, 207-225.

Miles, S. L., Fischer, A. P., Joshi, S. J., Niles, R.M., 2015. Ascorbic acid and ascorbate-2-phosphate decrease HIF activity and malignant properties of human melanoma cells. BMC Cancer. 15(1), 867.

Min, H. K., Kim, S. M., Baek, S. Y., Woo, J. W., Park, J. S., Park, S. H., 2015. Anthocyanin extracted from black soybean seed coats prevents autoimmune arthritis by suppressing the development of Th17 cells and synthesis of proinflammatory cytokines by such cells, via inhibition of NF-кB. PLoS One. 10(11), e0138201. Moraes, F. P., 2014. Suco desidratado de caju (Anacardium occidentale L.) por atomização: caracterização físico-química, bioativa e estudo da vida de prateleira do produto. [Dissertação]. UFRN. 122p.

Nayak, C.A., Srinivas, P., Rastogi, N. K., 2010. Characterization of anthocyanin from Garcinia indica Choisy. Food Chem. 118, 719-724.

Niizu, P. Y., Rodriguez-Amaya, D. B., 2005. New data on the carotenoid composition of raw salad vegetables. J Food Comp. Anal. 18(8), 739-749.

Oszmiański, J., Nowicka, P., Teleszko, M., Wojdyło, A., Cebulak, T., Oklejewicz, K., 2015. Analysis of phenolic compounds and antioxidant activity in wild blackberry fruits. Int. J. Mol. Sci. 16(7), 14540-14553.

Ozkan, G., Kamiloglu, S., Ozdal, T., Boyacioglu, D., Capanoglu, E., 2016. Potential use of Turkish medicinal plants in the treatment of various diseases. Molecules. 21(3), 257.

Palapol, Y., Ketsa, S., Stevenson, D., Cooney, J. M., Allan, A. C., Ferguson, I. B., 2009. Colour development and quality of mangosteen (Garcinia mangostana L.) fruit during ripening and after harvest. Postharvest Biol. Technol. 51, 349-353. 
Pem, D., Jeewon, R., 2015. Fruit and vegetable intake: Benefits and progress of nutrition education interventions - narrative review article. Iran J. Public Health. 44(10), 1309-1321.

Permana, D., Abas, F., Maulidiani, Shaari, K., Stanlas, J., Ali, A. M. Lajis, N. H., 2005. Atrovirisidone B, a new prenylated depsidone with cytotoxic property from the roots of Garcinia atroviridis. Z. Naturforsch C. 60(7-8), 523-526.

Reis, R. C., Viana, E. S., Jesus, J. L., Dantas, J. L. L., Lucena, R. S., 2015. Caracterização físico-química de frutos de novos híbridos e linhagens de mamoeiro. Pes. Agrop. Bras. 50(3), 210-217.

Rocha, M. S., Figueiredo, R. W., Araújo, M. A. M., 2013. Caracterização físico-química e atividade antioxidante (in vitro) de frutos do cerrado Piauiense. Rev. Bras. Frutic. 35(4), 933-941.

Rodriguez-Amaya, D. B., 1997. Carotenoids: Propriedades e funções. In: Ciência de Alimentos: Avanços e Perspectivas na América Latina, Fundação Cargill.

Rodriguez-Bernaldo, Q. A., Costa, H. S., 2006. Analysis of carotenoids in vegetable and plasma samples: A review. J. Food Comp. Anal. 19(2), 97-111.

Roque, D. W. B., Neto, E. F. A., Silveira, H. S. G., Sousa, A. B. B, Araújo, A. K. P., 2011. Caracterização físicoquímica de polpa de mangostão (Garcinia mangostana L.) comercializada em Santa Izabel do Pará-PA. Cad. V Agroecol. Des. Sustent. 1(1).

Rosa, F. R., Arruda, A. F., Siqueira, E. M. A, Arruda, S. F., 2016. Phytochemical compounds and antioxidant capacity of Tucum-Do-Cerrado (Bactris setosa Mart), Brazil's native fruit. Nutrients. 8(3), E110.

Rufino, M. S. M., 2008. Propriedades funcionais de frutas tropicais brasileiras não convencionais [tese] Mossoró (RN): Universidade Federal Rural do Semi-Árido. $237 f$.

Rutkowski, M., Grzegorczyk, K., 2012. Adverse effects of antioxidative vitamins. Int. J. Occup. Med. Environ. Health. 25(2), 105-121.

Samman, S., Sivarajah, G., Man, J. C., Ahmad, Z. I., Petocz, P., Caterson, I. D., 2003. A mixed fruit and vegetable concentrate increases plasma antioxidant vitamins and folate and lowers plasma homocysteine in men. J. Nutr. 133(7), 2188-2193.

Santos, M. B., Cardoso, R. L., Fonseca, A. A. O., Conceição, M. N., 2011. Caracterização e qualidade de Fruit de umbu-cajá (Spondays tuberosa X $\quad$ S. mombin) provenientes do Recôncavo Sul da Bahia. Rev. Bras. Fruticult. 32(4), 1089-1087.

Santos, M. L., Machado, A. V., Alves, F. M. S., Costa, A. P. L. M., 2013. Estudo físico-químico de maçã desidratada em secador convectivo. Rev. Verde. 8(1), 30-37.

Sato, Y., Mera, H., Takahashi, D., Majima, T., Iwasaki, N., Takagi, M., 2015. Synergistic effect of ascorbic acid and collagen addition on the increase in type 2 collagen accumulation in cartilage-like MSC sheet. Cytotechnol. $16,1-12$.

Sharma, P. B., Handique, P. J., Devi, H. S., 2015. Antioxidant properties, physico-chemical characteristics and proximate composition of five wild fruits of Manipur, India. J. Food Sci. Technol. 52(2), 894-902.

Silva, A. G., Constant, P. B. L., Sabaa-Srur, A. U. O., Sacramento, C. K., Stringheta, P. C., Gimenes, M. A. P., Maia, M. C. A., 2010. Potencial nutritivo de polpa de mangostão (Garcinia mangostana L.) cultivado nos estados do Pará e Bahia. J Magistra. 22(3), 178-184.

Silva, M. R., Santos Jr, R. T. O., Ferreira, C. C. C., 2008. Estabilidade da Vitamin $\mathrm{C}$ em cagaita in natura e durante a estocagem da polpa e refresco. Pes. Agrop. Tropical. 38(1), 53-58.

Silveira, D. S. P., de Siqueira, E. L., Pereira, C. S., Salomão, L. C. C., Struiving, T. B., 2009. Caracterização de Frutos de 15 cultivares de mangueira na Zona da Mata mineira. Rev. Ceres. 56(6), 783-789.

Sivakumari, K., Manimekalai, I., Ashok, K. R., 2016. Phytochemical profiling of mangosteen fruit, Garcinia mangostana. World J. Pharm. Pharmceut. Sci. 5(2), 221 252.

Skrovankova, S., Sumczynski, D., Mlcek, J., Jurikova, T., Sochor, J., 2015. Bioactive compounds and antioxidant activity in different types of berries. Int. J. Mol. Sci. 16(10), 24673-24706.

Stark, T. D., Salger, M., Frank, O., Balemba, O. B., Wakamatsu, J., Hofman, T., 2015. Antioxidative compounds from Garcinia buchananii stem bark. J. Nat. Prod. 78(2), 234-240.

Sucupira, N. R., Silva, A. B., Pereira, G., Costa, J. N., 2012. Métodos para determinação da atividade antioxidante de frutos. J. Health Sci. 14(4), 263-269.

Sukatta, U., Takenaka, M., Ono, H., Okadome, H., Sotome, I., Nanayama, K., Thanapase, W., Isobe, S., 2013. Distribution of major xanthones in the pericarp, aril, and yellow gum of mangosteen (Garcinia mangostana Linn.) fruit and their contribution to antioxidative activity. Biosci. Biotechnol. Biochem. 77(5), 984-987.

Suttirak, W., Manurakchinakorn, S., 2014. In vitro antioxidant properties of mangosteen peel extract. J. Food Sci. Technol. 51(12), 3546-3558.

Teixeira, T. N., 2011. Compostos fitoquímicos em polpas de pequi (Caryocar brasiliense camb.) de duas regiões do cerrado mineiro. Nutrire. 36(s), 264-264.

Tonin, F. S., Steimbach, L. M., Wiens, A., Perlin, C. M., Pontarolo, R., 2015. Impact of natural juice consumption on plasma antioxidant atatus: A systematic review and meta-analysis. Molecules. 20(12), 22146-22156.

Virgolin, L. B., 2015. Caracterização Físico-Química de Polpas de Frutas do Bioma Amazônia [dissertação]. São José do Rio Preto (SP): Instituto de Biociências, Letras e Ciências Exatas, Universidade Estadual Paulista. 58f.

Wihastuti, T. A., Sargowo, D., Tjokroprawiro, A., Permatasari, 
N., Widodo, M. A., Soeharto, S., 2014. Vasa vasorum anti-angiogenesis through $\mathrm{H}_{2} \mathrm{O}_{2}$, HIF- $1 \alpha$, NF- $\kappa \mathrm{B}$, and iNOS inhibition by mangosteen pericarp ethanolic extract (Garcinia mangostana Linn.) in hypercholesterol-dietgiven Rattus norvegicus Wistar strain. Vas Health Risk Manag. 10, 523-531.
Zeraik, M. L., 2010. Maracujá: um alimento funcional? Braz. J. Pharmacog. 20(3), 459-471.

Zhang, M., Chena, H., Mujumdarc, A. S, Tangd, J., Miaoe, S., Wanga, Y., 2015. Recent developments in high-quality drying of vegetables, fruits and aquatic products. Crit. Rev. Food Sci. Nutr. 33(13) [Epub ahead of print].

\section{How to cite this article:}

Farinazzi-Machado, F. M. V., Barbalho, S. M., Guiguer, E. L., Marinelli, P. S., Ishida, I. B., Vieites, R. L., Groppo, M., 2016. Phytochemical screening of the fruit of Garcinia cochinchinensis Choisy. Int. J. Curr. Res. Biosci. Plant Biol. 3(7), 81-89. doi: http://dx.doi.org/10.20546/ijcrbp.2016.307.012 